\title{
Food Web Structure and Trophic Interactions Revealed by Stable Isotope Analysis in the Midstream of the Chishui River, a Tributary of the Yangtze River, China
}

\author{
Qiang Qin ${ }^{1,2}$, Fubin Zhang ${ }^{3}$, Fei Liu ${ }^{1}$, Chunling Wang ${ }^{1}$ and Huanzhang Liu ${ }^{1, *}$ \\ 1 The Key Laboratory of Aquatic Biodiversity and Conservation of Chinese Academy of Sciences, \\ Institute of Hydrobiology, Chinese Academy of Sciences, Wuhan 430072, China; qinqiang@ihb.ac.cn (Q.Q.); \\ liufei@ihb.ac.cn (F.L.); chwang@ihb.ac.cn (C.W.) \\ 2 University of Chinese Academy of Sciences, Beijing 100049, China \\ 3 College of Environmental Science and Engineering, China West Normal University, Nanchong 637009, China; \\ sczhangfubin@163.com \\ * Correspondence: hzliu@ihb.ac.cn; Tel.: +86-27-6878-0776
}

check for updates

Citation: Qin, Q.; Zhang, F.; Liu, F.; Wang, C.; Liu, H. Food Web Structure and Trophic Interactions Revealed by Stable Isotope Analysis in the

Midstream of the Chishui River, a Tributary of the Yangtze River, China. Water 2021, 13, 195. https://doi.org/ 10.3390/w13020195

Academic Editor: Jan Janse Received: 27 October 2020 Accepted: 12 January 2021 Published: 15 January 2021

Publisher's Note: MDPI stays neutral with regard to jurisdictional clai$\mathrm{ms}$ in published maps and institutional affiliations.

Copyright: $(\odot 2021$ by the authors. Licensee MDPI, Basel, Switzerland. This article is an open access article distributed under the terms and conditions of the Creative Commons Attribution (CC BY) license (https:// creativecommons.org/licenses/by/ $4.0 /)$.

\begin{abstract}
Understanding energy flow and nutrient pathways is crucial to reveal the dynamics and functions of riverine ecosystems and develop appropriate conservation strategies. In this study, we utilized stable isotopes of $\delta^{13} \mathrm{C}$ and $\delta^{15} \mathrm{~N}$ to examine the fundamental characteristics of trophic position, trophic niche, and carbon source for the food web in the midstream of the Chishui River, a tributary to the Yangtze River. Our results showed that stable isotope signatures among different sorts of basal resources and consumers were significantly distinguishable and that the food chain consisted of four trophic levels, indicating the multiple trophic pathways and long food chain length here. The trophic guilds of fish were classified into four categories, in which herbivorous and carnivorous fish showed greater trophic diversity and omnivorous fish had higher trophic redundancy, which meant that there was a stable trophic niche structure in the study area. Phytoplankton and periphyton presented the largest contributions to consumers, indicating that autochthonous productivity was the dominant carbon source in the midstream of the Chishui River. Since the Chishui River is still in a natural condition without any dam constructions, the autochthonous productivity, stable trophic niche structure, multiple trophic pathways and long food chain length found here demonstrate its high conservation value. Therefore, the strategy to refrain from damming on this river should persist into the future.
\end{abstract}

Keywords: stable isotopes; biodiversity and conservation; dam construction; riverine ecosystem; the Yangtze River

\section{Introduction}

The energy flow and nutrient pathways are fundamental characteristics of any ecosystem [1-3]. The riverine ecosystem, as a distinctive system offering food resources and habitats for aquatic organisms, has received constant attention from ecologists [4,5]. Studies of food web structure and trophic interactions provide information on energy flow and nutrient pathways, which can be used to investigate the dynamics and functions of riverine ecosystems [6,7]. The knowledge of trophic position, trophic niche, and carbon source are key components of food web studies that help us to understand species coexistence, niche structure and species distribution, and enable us to predict changes of ecosystem properties and bottom-up and top-down processes, thereby providing a basis for biodiversity conservation and ecosystem management [8-10].

The concept of trophic position, reflecting energy flow through the food web, has enabled valuable insights into the functioning of riverine ecosystems, including the determination of trophic pathways and food chain length [7]. Schoener [11] and Hutchinson [12] 
found that trophic position in a given food web was limited by energy availability-longer food chain length and more diverse trophic pathways corresponded to a greater number of energy flows within the food web, indicating that trophic pathways and food chain length increase with ecosystem productivity. Similarly, Kaymak et al. [13] and Hoeinghaus et al. [14] examined trophic position in the Tozanli River, Turkey, and Parana River, Brazil, respectively, and found that un-impounded riverine ecosystems had higher productivity that could sustain multiple trophic pathways and greater food chain length, in comparison to impounded riverine ecosystems through, e.g., dam construction. Dam construction decreased the number of trophic pathways and restricted the food chain length of food webs in these riverine ecosystems because it altered hydrological flow regimes (e.g., water depth and velocity, magnitude and duration of flow pulses) and floodplain interactions (e.g., sediment dynamics), negatively supporting higher trophic levels and reducing the number of trophic pathways.

The metric of trophic niche quantitatively describes the actual space (e.g., predation scope) or potential utilization (e.g., prey species and size) of consumers and resources, providing a perspective from which to characterize the trophic diversity and redundancy related to ecosystem stability [15]. For instance, McCann [16] and Odum [17] reported that higher trophic diversity and redundancy increased the channels of nutrient availability and offset the impacts of the loss of certain species, indicating that trophic diversity and redundancy would give rise to ecosystem stability. In contrast, Pruell et al. [18] and Kaymak et al. [13] suggested that anthropogenic impacts, such as nutrient inputs or the barrier of dams, would alter the food web structure in riverine ecosystems and that this could significantly decrease the trophic diversity and trophic niche space, thereby reducing ecosystem stability. Therefore, determining the realized trophic niche can provide empirical evidence that helps us to understand trophic interactions and how changes might affect ecosystem stability.

The study of carbon sources is typically used to interpret the importance of autochthonous and allochthonous organic matter, which is related to the river continuum concept, flood pulse concept, and riverine productivity concept [19]. The river continuum concept emphasizes that a continuous carbon transformation of terrestrial inputs from upstream reaches is crucial in riverine systems [20]. The flood pulse concept stresses that the organic matter supporting riverine ecosystems comes from the lateral floodplain [21]. Both of these concepts highlight the fact that riverine ecosystems derive a significant amount of allochthonous organic carbon from terrestrial parts. The riverine productivity concept states that carbon sources in riverine ecosystems mainly originate from the local autochthonous productivity of aquatic vegetation and riparian zone [22]. Thorp et al. [23] proposed that autochthonous organic matter in riverine ecosystems is more labile and may be assimilated by consumers in larger proportions despite its lower abundance. Huang et al. [24] also showed that autochthonous productivity was the key contributor for the majority of riverine ecosystems in tropical and subtropical areas. Angradi [25] and Pingram et al. [19] found that dam construction changed the natural flow regimes and the shifts in hydrogeomorphology might increase phytoplankton production and terrestrial inputs, and the subsidies from phytoplankton production and terrestrial inputs could affect the availability and abundance of basal resources to consumers in the food web, leading to potential alterations in the carbon sources that support the food web of riverine ecosystems. However, the main energy resource variations in dammed rivers are still not clear. Thus, evaluating the carbon source in riverine ecosystems can help us understand their trophic status.

Stable isotope analysis is a powerful tool that has been widely used to determine energy flows and nutrient pathways in food webs of different aquatic ecosystems [26-28]. For example, studies have utilized stable isotopes of $\delta^{13} \mathrm{C}$ and $\delta^{15} \mathrm{~N}$ to identify the dietary variability, feeding strategy, trophic position, trophic niche shift, and nutrient source for food webs $[15,29]$. Generally, the stable isotope of $\delta^{15} \mathrm{~N}$, reflecting species resource use, was used to determine the trophic position of organisms [30,31]. The stable isotope of $\delta^{13} \mathrm{C}$, 
as an indicator for organic matter transfers, was usually used to trace the original source of carbon [31,32]. In addition, developments of Bayesian mixing models and community-wide metrics in conjunction with stable isotopes of $\delta^{13} \mathrm{C}$ and $\delta^{15} \mathrm{~N}$ allowed estimations of the contribution of possible prey items and the space of isotopic niche occupied by consumers in a given food web [33].

The Chishui River is an important part of the National Nature Reserve for rare and endemic fish of the upper Yangtze River. It is the only undammed tributary in the upper Yangtze River basin; as such, it provides a last refuge for aquatic organisms (e.g., Hemiculterella sauvagei, Bangana rendahli, Ancherythroculter kurematsui) that are suffering from risks due to the dam projects such as the Three Gorges Dam, which caused habitat loss and changed environmental factors for aquatic organisms [34]. The Chishui River is a typical subtropical mountain river with high biodiversity, especially for endemic fish of the upper Yangtze River, the survival and reproduction of which depend on rapid water flow without the barrier of dams [35]. Until now, studies on energy flows and nutrient pathways in the Chishui River have been scarce: Zhang et al. [36] and Liu [37] described the trophic structure and food source in headwater and downstream reaches using gut content analysis. It is essential to explore the Chishui River's ecosystem structure and function to evaluate its conservation value.

Within this context, we utilized stable isotopes of $\delta^{13} \mathrm{C}$ and $\delta^{15} \mathrm{~N}$ to examine the trophic position, trophic niche, and carbon source for the food web to examine the energy flows and nutrient pathways in the midstream of the Chishui River. Specifically, we aimed to explore (1) whether the ecosystem can sustain multiple trophic pathways and long food chain length, (2) whether a stable trophic niche structure with high trophic diversity and redundancy could be observed in the food web, and (3) whether autochthonous organic matter is the dominant carbon source in the midstream of the Chishui River. Based on the results obtained, we then propose strategies for biodiversity conservation and riverine ecosystem management in the area.

\section{Materials and Methods}

\subsection{Study Area}

The Chishui River $\left(27^{\circ} 20^{\prime}-28^{\circ} 50^{\prime} \mathrm{N}, 104^{\circ} 45^{\prime}-106^{\circ} 51^{\prime} \mathrm{E}\right)$, a tributary of the upper Yangtze River, originates from North of the Wumeng Mountains in Zhenxiong County, Yunnan Province, and flows through Yunnan, Guizhou and Sichuan Provinces, China (Figure 1). It has a total length of $436.5 \mathrm{~km}$ with a natural fall of $1473.9 \mathrm{~m}$ and a watershed area of $21,010 \mathrm{~km}^{2}$ [35]. The river can be divided into three sections: the upstream reaches $224.7 \mathrm{~km}$ long with $1274.8 \mathrm{~m}$ natural fall and ranges from the source to Maotai Town; the midstream reaches $157.8 \mathrm{~km}$ long with $182.9 \mathrm{~m}$ natural fall and extends from Maotai Town to Chishui City; and the downstream reaches $54 \mathrm{~km}$ long with $16.2 \mathrm{~m}$ natural fall and stretches from Chishui City to the confluence with the Yangtze River in Hejiang County [38].

In this study, we collected samples in the $18 \mathrm{~km}$ long reaches of Chishui City $\left(28^{\circ} 29^{\prime}-\right.$ $28^{\circ} 36^{\prime}$ N, $105^{\circ} 40^{\prime}-105^{\circ} 45^{\prime}$ E; Figure 1), which extend from Fuxin Town to Lianyuxi Village in the midstream of the Chishui River. This region is located in the border area of Yungui Altiplano and Sichuan Basin in southwestern China, and the topography is dominated by typical Danxia landforms, which are characterized by a red-bedded geomorphology of steep cliff slopes [35]. The study area is characterized by a subtropical monsoon climate with water temperatures from $8.8^{\circ} \mathrm{C}$ in January to $26^{\circ} \mathrm{C}$ in August, and an average annual rainfall of about $1200 \mathrm{~mm}$ [38]. The reaches flow in channels with a softer slope and the substrates of the riverbed are a mix of laterite and boulders [34]. 


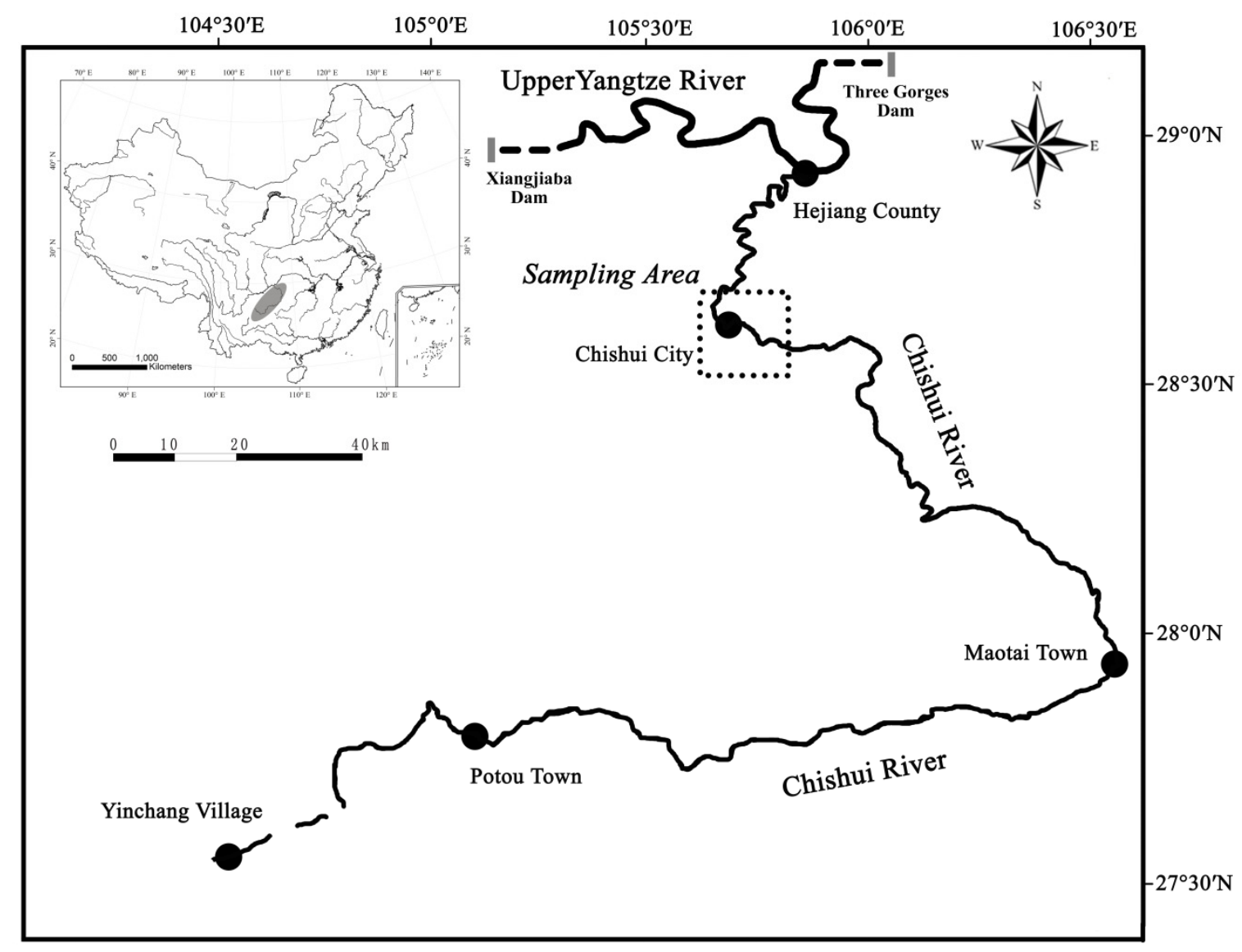

Figure 1. Map of study area (dashed box) in the Chishui River basin (shaded part). Dotted lines represent the simplification of the river reaches.

\subsection{Sample Collection}

All samples for stable isotope analysis were collected from March to July 2015 (the sampling was mainly concentrated in late March to mid-April and some uncommon fish species were supplemented from May to July) in the midstream of the Chishui River. The basal resources and consumers were selected for stable isotope analysis. The basal resources included phytoplankton, particulate organic matter (POM), sedimentary organic matter (SOM), terrestrial vascular plants, aquatic vascular plants and periphyton. For the phytoplankton samples, about $10 \mathrm{~L}$ of surface water was sampled with a water bottle and pre-filtered through a plankton net (112 $\mu \mathrm{m}$ mesh size) to remove zooplankton and large detritus, and the phytoplankton samples were obtained by previously filtering the filtrate with a plankton net ( $64 \mu \mathrm{m}$ mesh size) and then further filtering the resultant suspension on Whatman GF/F glass fiber filters (pre-combusted at $450{ }^{\circ} \mathrm{C}$ for $4 \mathrm{~h}$, the same below). The POM samples were obtained by pre-filtering $10 \mathrm{~L}$ of surface water through a plankton net (64 $\mu \mathrm{m}$ mesh size) and then further filtering the filtrate through Whatman GF/F glass fiber filters. The SOM samples were collected by cylindrical PVC pipes at a depth of about $2 \mathrm{~cm}$ from the surface of sediments. Terrestrial vascular plants were collected from the riverbank by hand. Aquatic vascular plants were collected from shallow areas by hand. Periphyton was sampled from the riverbed or scraped from ship hulls. Terrestrial vascular plants, aquatic vascular plants, and periphyton were rinsed with distilled water several times to remove organisms, sediments, and any other attachments.

The consumers consisted of zooplankton, mollusks, crustaceans, aquatic insects and fish. The zooplankton samples were collected by trawling a plankton net $(112 \mu \mathrm{m}$ mesh size) on the surface water for $10 \mathrm{~min}$. The mollusks and aquatic insects were sampled by a $\mathrm{D}$-framed hand net from the riverbed. The fish were collected by gillnets $(10 \mathrm{~m}$ long $\times 1.5 \mathrm{~m}$ 
high, 5 and $10 \mathrm{~cm}$ mesh size), trap-nets ( $5 \mathrm{~m}$ long), and fishhooks. The crustaceans were also caught along with the fish. Once captured, mollusks, crustaceans and aquatic insects were immediately distinguished, referring to Duan et al. [39] and Morse et al. [40]. Fish samples were identified to species level following Ding [41] and Chen [42]; they were then measured and we recorded the general biological data in the field. All samples were preserved in a portable ice box brought to the temporary laboratory. In this study, 1-5 samples of each species were selected for analysis and fish samples included the dominant fish species (a total of 37 species comprise over $90 \%$ of the total fish biomass) in the midstream of the Chishui River.

In the laboratory, zooplankton, mollusks and aquatic insects were kept alive in distilled water for $24 \mathrm{~h}$ to empty the gut contents, and then zooplankton samples were filtered onto Whatman GF/F glass fiber filters. The adductor muscle tissue of mollusks, dorsal and foot muscle tissue of crustaceans, dorsal muscle tissue between the lateral line and dorsal fin (with the skin and bone removed) of fish, and the whole body of aquatic insects were processed for stable isotope analysis. The POM, SOM, phytoplankton, and zooplankton samples were carefully washed with acid by $1 \mathrm{~mol} / \mathrm{L} \mathrm{HCl}$ to remove any carbonates. Finally, all samples were dried at $60{ }^{\circ} \mathrm{C}$ for at least $48 \mathrm{~h}$ in an oven and were grounded to a homogenous fine powder with a mortar and pestle. Samples in the form of powder were stored in clean containers until analysis.

\subsection{Stable Isotope Analysis}

The stable isotope values of $\delta^{13} \mathrm{C}$ and $\delta^{15} \mathrm{~N}$ were determined at the research group of fish ecology and conservation biology, Institute of Hydrobiology, Chinese Academy of Sciences. The powder samples weighing approximately 200-1000 ug were transferred into tin capsules and we measured their stable isotope values using a Delta V Advantage mass spectrometer coupled to a Flash 2000 HT elemental analyzer (Thermo Fisher Scientific, Waltham, MA, USA). Stable isotope values were represented by the $\delta$ notation according to the following equation: $\delta X(\%)=\left[\left(R_{\text {sample }} / R_{\text {standard }}\right)-1\right] \times 1000$, where $X$ is ${ }^{13} \mathrm{C}$ or ${ }^{15} \mathrm{~N}$ and $R$ represents the stable isotope ratio $\left({ }^{13} \mathrm{C} /{ }^{12} \mathrm{C}\right.$ for carbon, ${ }^{15} \mathrm{~N} /{ }^{14} \mathrm{~N}$ for nitrogen). The $\delta$ notation is in units of parts per mil (\%o). The standard reference materials were based on Vienna Pee Dee Belemnite (VPDB) for carbon and atmospheric $\mathrm{N}_{2}$ for nitrogen $[43,44]$. In this study, USGS40, USGS41, and UREA-Thermo were used as working standard materials and interspersed in the sequence. The analytical precision for both $\delta^{13} \mathrm{C}$ and $\delta^{15} \mathrm{~N}$ was approximately $0.1 \%$.

\subsection{Data Analysis}

The divergence of $\delta^{13} \mathrm{C}$ and $\delta^{15} \mathrm{~N}$ for different sorts of basal resources and consumers was detected by the Kruskal-Wallis non-parametric ANOVA test [45]. The trophic level (TL) was calculated by the following formula: $T L=\left(\delta^{15} N_{\text {consumer }}-\delta^{15} N_{\text {baseline }}\right) / 3.4+\lambda$, where $\delta^{15} \mathrm{~N}_{\text {consumer }}$ is the stable isotope value of the consumer being calculated, $\delta^{15} \mathrm{~N}_{\text {baseline }}$ is the stable isotope value of the baseline organism, 3.4 indicates the trophic fractionation of $\delta^{15} \mathrm{~N}$ per trophic level, and $\lambda$ represents the trophic level of the baseline organism [31]. In this study, Limnoperna lacustris, which was assumed to exclusively feed on simple basal resources, was chosen as the baseline organism and $\lambda$ was attributed as trophic level 2. A hierarchical cluster analysis based on Bray-Curtis similarity was performed on $\delta^{13} \mathrm{C}$ and $\delta^{15} \mathrm{~N}$ values to assign the trophic guild of fish, and feeding types of fish were assigned from the literature $[36,46]$. Non-metric multidimensional scaling (NMDS) was used to verify the trophic guild classification and analysis of similarities (ANOSIM) was conducted to examine the differences among all pairs of trophic guilds [47]. Global $R$-statistic values of ANOSIM, which oscillate from -1 to +1 , represent the degree of similarity between guilds. $R$-statistic values close to 0 indicate no difference between guilds, while $R$-statistic values close to -1 or +1 correspond to a significant divergence between guilds. Results were considered statistically significant at $p$-values of less than 0.05 . 
We used the trophic niche metrics proposed by Layman [15] to estimate the trophic niche of fish in the midstream of the Chishui River. The $\delta^{15} \mathrm{~N}$ range (NR) is the distance from the most depleted to the most enriched $\delta^{15} \mathrm{~N}$ values between species and provides information regarding food chain length. The $\delta^{13} \mathrm{C}$ range (CR) is the distance from the most depleted to the most enriched $\delta^{13} \mathrm{C}$ values between species and is used to estimate the diversity of food sources. The total area of the convex hull (TA) and corrected standard ellipse area (SEAc) represent the total niche space and core niche space occupied by species, respectively, and are considered as proxies for niche breadth. The mean distance to the centroid (CD) is the average Euclidean distance of each species to the centroid and provides information about the average degree of trophic diversity. The mean nearest neighbor distance (MNND) is the mean Euclidean distance to each species' nearest neighbor, providing a measure of overall density of species packing. The standard deviation of nearest neighbor distance (SDNND) is a measure of the evenness of species packing. Low MNND and SDNND values suggest increased trophic redundancy.

Finally, the SIAR mixing model based on the Bayesian linear equations was used to determine the proportional contributions of basal resources to consumers [48]. Previous studies reported that the trophic fractionations were from $0 \%$ to $1 \%$ in $\delta^{13} \mathrm{C}$ and from $3 \%$ to $4 \%$ in $\delta^{15} \mathrm{~N}$ between neighbor trophic levels in aquatic ecosystems [49]. The trophic fractionation conducted in the SIAR mixing model, as used in this study, was proposed by Post [31] for $\delta^{13} \mathrm{C}(0.40 \pm 1.30 \%)$ and $\delta^{15} \mathrm{~N}(3.40 \pm 1.00 \%$ o $)$.

Statistical analyses were conducted in the software of PAST 3.0 [50], PRIMER 5.2.9 [51], and packages 'SIBER' and 'SIAR' in R 3.6.1 [52].

\section{Results}

\subsection{Isotopic Values and Trophic Levels}

In this study, significant differences were observed in $\delta^{13} \mathrm{C}$ and $\delta^{15} \mathrm{~N}$ values among the different sorts of basal resources (Kruskal-Wallis ANOVA, $p<0.01$ ). The $\delta^{13} \mathrm{C}$ values of basal resources ranged from $-32.14 \pm 0.73 \%$ o to $-21.54 \pm 0.31 \%$, of which the aquatic vascular plant Alternanthera philoxeroides expressed the highest $\delta^{13} \mathrm{C}$ depletion and the periphyton Chara showed the highest $\delta^{13} \mathrm{C}$ enrichment (Table 1, Figure 2). The $\delta^{15} \mathrm{~N}$ values of basal resources varied from $0.97 \pm 0.30 \%$ to $6.36 \pm 0.24 \%$ (Table 1 ). The periphyton Chara was the most $\delta^{15} \mathrm{~N}$ depleted and phytoplankton were the most $\delta^{15} \mathrm{~N}$ enriched (Figure 2). 
Table 1. Stable isotope $\left(\delta^{13} \mathrm{C}\right.$ and $\left.\delta^{15} \mathrm{~N}\right)$ signatures for basal resources and consumers in the midstream of the Chishui River.

\begin{tabular}{|c|c|c|c|c|c|c|c|c|}
\hline \multirow{2}{*}{ Species } & \multirow{2}{*}{ Code } & \multirow{2}{*}{$n$} & \multirow{2}{*}{ Feeding Type } & \multicolumn{2}{|c|}{$\delta^{13} \mathrm{C}(\%)$} & \multicolumn{2}{|c|}{$\delta^{15} \mathrm{~N}(\%)$} & \multirow{2}{*}{ TL } \\
\hline & & & & Range & Mean \pm SD & Range & Mean \pm SD & \\
\hline \multicolumn{9}{|l|}{ Basal resources } \\
\hline POM & POM & 4 & & -26.39 to -25.48 & $-25.83 \pm 0.34$ & 1.91 to 2.78 & $2.42 \pm 0.32$ & \\
\hline SOM & SOM & 3 & & -27.20 to -27.11 & $-27.14 \pm 0.04$ & 1.19 to 2.26 & $1.75 \pm 0.44$ & \\
\hline \multicolumn{9}{|l|}{ Terrestrial vascular plants } \\
\hline Bamboo leaves & B.lea & 3 & & -28.29 to -27.08 & $-27.62 \pm 0.51$ & 4.20 to 5.73 & $5.15 \pm 0.68$ & \\
\hline Conyza canadensis & C.can & 3 & & -31.84 to -30.79 & $-31.25 \pm 0.44$ & 0.85 to 1.77 & $1.43 \pm 0.41$ & \\
\hline \multicolumn{9}{|l|}{ Aquatic vascular plants } \\
\hline Alternanthera philoxeroides & A.phi & 3 & & -32.70 to -31.10 & $-32.14 \pm 0.73$ & 2.48 to 4.46 & $3.26 \pm 0.86$ & \\
\hline $\begin{array}{c}\text { Polygonum hydropiper } \\
\text { Periphyton }\end{array}$ & P.hyd & 3 & & -30.65 to -29.71 & $-30.15 \pm 0.38$ & 3.01 to 5.89 & $4.71 \pm 1.23$ & \\
\hline Filamentous green algae & F.alg & 3 & & -23.93 to -23.21 & $-23.55 \pm 0.30$ & 0.51 to 1.47 & $1.03 \pm 0.40$ & \\
\hline Chara & Char & 3 & & -21.93 to -21.17 & $-21.54 \pm 0.31$ & 0.64 to 1.37 & $0.97 \pm 0.30$ & \\
\hline \multicolumn{8}{|l|}{ Consumers } & \\
\hline $\begin{array}{c}\text { Invertebrates } \\
\text { Zooplankton } \\
\text { Zoobenthos } \\
\text { Mollusks }\end{array}$ & Zoop & 3 & & -26.01 to -25.18 & $-25.66 \pm 0.35$ & 4.96 to 6.83 & $5.74 \pm 0.79$ & 2.39 \\
\hline Bellamya quadrata & B.qua & 5 & & -24.07 to -21.83 & $-22.71 \pm 0.97$ & 2.59 to 3.26 & $3.00 \pm 0.30$ & 1.58 \\
\hline $\begin{array}{c}\text { Limnoperna lacustris } \\
\text { Crustaceans }\end{array}$ & L.lac & 3 & & -24.12 to -23.69 & $-23.93 \pm 0.18$ & 4.32 to 4.52 & $4.43 \pm 0.08$ & 2.00 \\
\hline Sinopotamon chishuiense & S.chi & 3 & & -23.50 to -22.67 & $-23.09 \pm 0.34$ & 6.27 to 7.95 & $7.15 \pm 0.69$ & 2.80 \\
\hline $\begin{array}{c}\text { Macrobranchium nipponense } \\
\text { Aquatic insects }\end{array}$ & M.nip & 3 & & -23.12 to -22.68 & $-22.94 \pm 0.18$ & 4.06 to 4.15 & $4.12 \pm 0.04$ & 1.91 \\
\hline Gomphidae larvae & G.lar & 2 & & -22.90 to -21.47 & $-22.18 \pm 0.71$ & 4.57 to 5.94 & $5.26 \pm 0.68$ & 2.24 \\
\hline $\begin{array}{c}\text { Cybister larvae } \\
\text { Fishes }\end{array}$ & C.lar & 3 & & -25.29 to -24.78 & $-25.12 \pm 0.24$ & 3.16 to 4.82 & $4.07 \pm 0.69$ & 1.89 \\
\hline Acrossocheilus monticolus $\star$ & A.mon & 5 & Benthivores & -25.20 to -23.71 & $-24.30 \pm 0.52$ & 10.33 to 11.11 & $10.61 \pm 0.28$ & 3.82 \\
\hline Ancherythroculter kurematsui $\star$ & A.kur & 5 & Benthivores & -23.89 to -22.89 & $-23.25 \pm 0.34$ & 7.46 to 10.00 & $8.84 \pm 0.93$ & 3.30 \\
\hline Bangana rendahli $\star$ & B.ren & 1 & Herbivores & --- & $-24.50 \pm 0.00$ & --- & $7.74 \pm 0.00$ & 2.98 \\
\hline Carassius auratus & C.aur & 5 & Detritivores & -22.58 to -20.40 & $-21.87 \pm 0.79$ & 6.95 to 10.71 & $8.59 \pm 1.47$ & 3.22 \\
\hline Ctenopharyngodon idellus & C.ide & 5 & Herbivores & -23.16 to -21.17 & $-22.20 \pm 0.83$ & 5.09 to 6.45 & $5.79 \pm 0.53$ & 2.40 \\
\hline Culter alburnus & C.alb & 4 & Omnivores & -23.71 to -22.65 & $-23.09 \pm 0.42$ & 7.55 to 9.15 & $8.45 \pm 0.62$ & 3.18 \\
\hline
\end{tabular}


Table 1. Cont.

\begin{tabular}{|c|c|c|c|c|c|c|c|c|}
\hline \multirow{2}{*}{ Species } & \multirow{2}{*}{ Code } & \multirow{2}{*}{$n$} & \multirow{2}{*}{ Feeding Type } & \multicolumn{2}{|c|}{$\delta^{13} \mathrm{C}(\%)$} & \multicolumn{2}{|c|}{$\delta^{15} \mathrm{~N}(\%)$} & \multirow{2}{*}{ TL } \\
\hline & & & & Range & Mean \pm SD & Range & Mean \pm SD & \\
\hline Culter mongolicus & C.mon & 4 & Piscivores & -22.92 to -21.71 & $-22.20 \pm 0.45$ & 8.56 to 9.29 & $9.05 \pm 0.29$ & 3.36 \\
\hline Cyprinus(Cyprinus) carpio & C.car & 5 & Omnivores & -23.64 to -21.43 & $-22.65 \pm 0.94$ & 5.22 to 9.93 & $7.21 \pm 1.76$ & 2.82 \\
\hline Gobiobotia filifer & G.fil & 3 & Benthivores & -23.18 to -21.80 & $-22.45 \pm 0.57$ & 8.84 to 10.15 & $9.53 \pm 0.54$ & 3.50 \\
\hline Hemibarbus labeo & H.lab & 5 & Benthivores & -23.43 to -22.60 & $-22.94 \pm 0.30$ & 8.14 to 10.43 & $9.31 \pm 0.84$ & 3.44 \\
\hline Hemibarbus maculatus & H.mac & 5 & Benthivores & -23.71 to -21.82 & $-22.61 \pm 0.69$ & 7.92 to 8.79 & $8.35 \pm 0.37$ & 3.16 \\
\hline Hemiculter tchangi $\star$ & H.tch & 5 & Detritivores & -24.72 to -23.16 & $-23.82 \pm 0.56$ & 6.25 to 7.47 & $6.85 \pm 0.50$ & 2.71 \\
\hline Hemiculterella sauvagei $\star$ & H.sau & 5 & Benthivores & -23.51 to -23.16 & $-23.28 \pm 0.12$ & 6.08 to 7.98 & $6.99 \pm 0.60$ & 2.75 \\
\hline Leiocassis crassilabris & L.cra & 5 & Omnivores & -22.87 to -21.60 & $-22.31 \pm 0.41$ & 7.85 to 11.04 & $10.11 \pm 1.21$ & 3.67 \\
\hline Leptobotia elongata $\star$ & L.elo & 5 & Piscivores & -22.36 to -21.85 & $-22.11 \pm 0.17$ & 8.55 to 11.76 & $10.37 \pm 1.36$ & 3.75 \\
\hline Megalobrama pellegrini $\star$ & M.pel & 2 & Benthivores & -21.29 to -21.14 & $-21.21 \pm 0.07$ & 8.20 to 8.25 & $8.22 \pm 0.02$ & 3.12 \\
\hline Mystus macropterus & M.mac & 5 & Benthivores & -21.98 to -21.58 & $-21.81 \pm 0.16$ & 8.71 to 11.58 & $9.65 \pm 1.04$ & 3.54 \\
\hline Onychostoma sima & O.sim & 3 & Herbivores & -25.28 to -23.55 & $-24.30 \pm 0.73$ & 5.03 to 8.17 & $6.92 \pm 1.36$ & 2.73 \\
\hline Parabotia bimaculata $\star$ & P.bim & 5 & Benthivores & -23.97 to -22.36 & $-23.52 \pm 0.59$ & 11.02 to 11.41 & $11.22 \pm 0.13$ & 4.00 \\
\hline Parabotia fasciata & P.fas & 3 & Benthivores & -23.84 to -22.45 & $-23.28 \pm 0.60$ & 11.02 to 12.19 & $11.52 \pm 0.50$ & 4.09 \\
\hline Pelteobagrus fulvidraco & P.ful & 5 & Omnivores & -21.76 to -20.32 & $-21.33 \pm 0.53$ & 9.39 to 9.97 & $9.68 \pm 0.20$ & 3.54 \\
\hline Pelteobagrus nitidus & P.nti & 5 & Omnivores & -22.65 to -22.18 & $-22.44 \pm 0.20$ & 8.08 to 10.24 & $8.70 \pm 0.82$ & 3.26 \\
\hline Procypris rabaudi $\star$ & P.rab & 5 & Benthivores & -22.92 to -21.78 & $-22.25 \pm 0.37$ & 8.47 to 10.43 & $9.83 \pm 0.73$ & 3.59 \\
\hline Pseudobagrus truncatus & P.tru & 5 & Benthivores & -24.39 to -22.13 & $-22.96 \pm 0.85$ & 7.13 to 9.55 & $8.37 \pm 0.85$ & 3.16 \\
\hline Pseudolaubuca sinensis & P.sin & 5 & Benthivores & -24.10 to -22.97 & $-23.51 \pm 0.44$ & 8.47 to 10.39 & $9.42 \pm 0.71$ & 3.47 \\
\hline Rhinogobio typus & R.typ & 5 & Benthivores & -24.05 to -22.81 & $-23.43 \pm 0.47$ & 7.80 to 10.78 & $9.33 \pm 1.27$ & 3.44 \\
\hline Saurogobio dabryi & S.dab & 5 & Detritivores & -22.62 to -22.36 & $-22.47 \pm 0.09$ & 7.47 to 8.40 & $7.88 \pm 0.30$ & 3.02 \\
\hline Silurus asotus & S.aso & 5 & Piscivores & -25.94 to -21.04 & $-24.56 \pm 1.80$ & 7.38 to 11.94 & $8.56 \pm 1.70$ & 3.22 \\
\hline Sinibrama macrops & S.mac & 1 & Herbivores & --- & $-25.22 \pm 0.00$ & --- & $5.77 \pm 0.00$ & 2.40 \\
\hline Siniperca chuatsi & S.chu & 5 & Piscivores & -23.41 to -22.14 & $-22.68 \pm 0.49$ & 10.12 to 11.44 & $10.69 \pm 0.44$ & 3.84 \\
\hline Siniperca scherzeri & S.sch & 1 & Piscivores & --- & $-22.32 \pm 0.00$ & --- & $12.81 \pm 0.00$ & 4.47 \\
\hline $\begin{array}{c}\text { Sinogastromyzon szechuanensis } \\
\text { Szechuanensis } \star\end{array}$ & S.sze & 5 & Benthivores & -25.01 to -24.26 & $-24.59 \pm 0.24$ & 9.71 to 10.76 & $10.15 \pm 0.38$ & 3.68 \\
\hline Spinibarbus sinensis & S.sin & 5 & Benthivores & -23.45 to -21.78 & $-22.65 \pm 0.67$ & 5.06 to 7.94 & $7.19 \pm 1.07$ & 2.81 \\
\hline Squalidus argentatus & S.arg & 5 & Benthivores & -22.84 to -22.26 & $-22.54 \pm 0.20$ & 7.22 to 8.11 & $7.83 \pm 0.33$ & 3.00 \\
\hline Xenocypris davidi & X.dav & 1 & Omnivores & --- & $-24.86 \pm 0.00$ & --- & $8.76 \pm 0.00$ & 3.28 \\
\hline
\end{tabular}

$n$ represents number of samples analyzed, SD represents standard deviation, TL represents trophic level, $\star$ represents endemic species of the upper Yangtze River. 


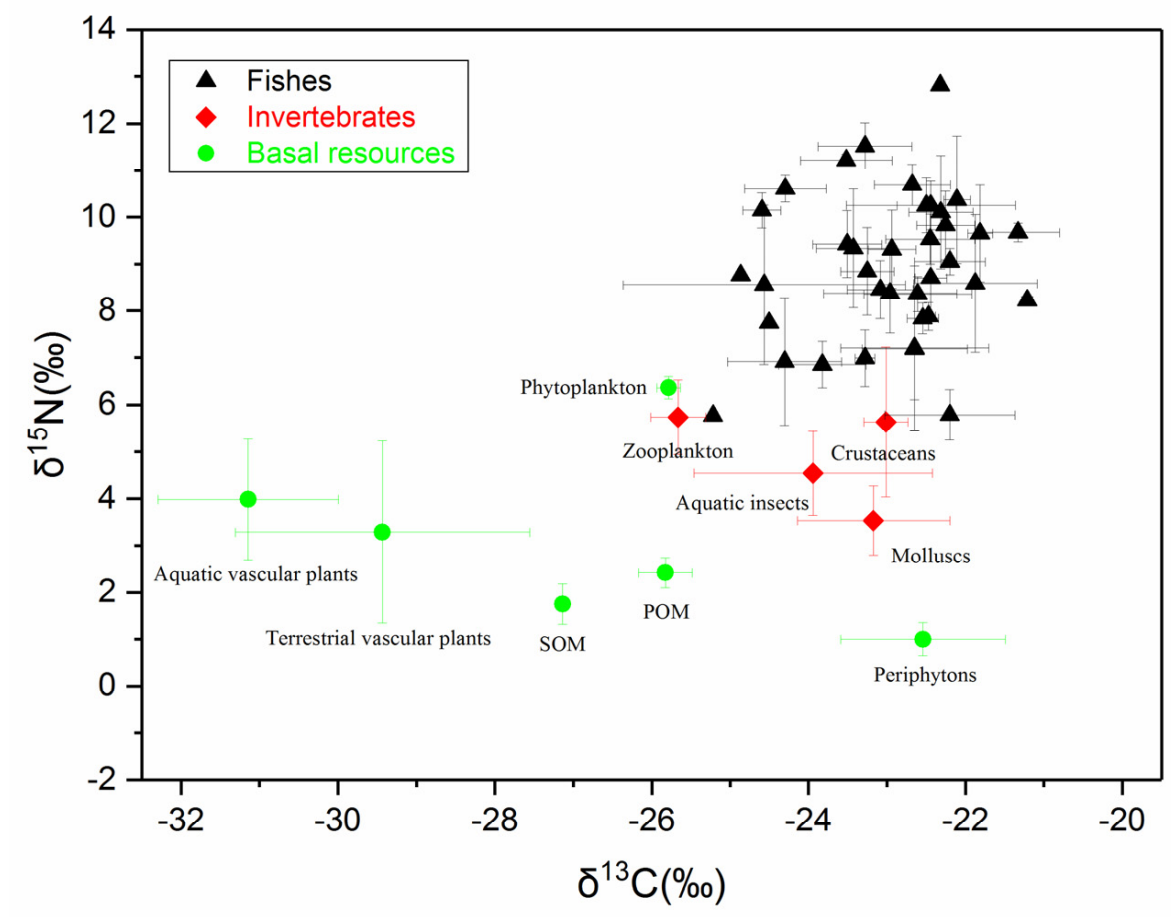

Figure 2. Stable isotope $\left(\delta^{13} \mathrm{C}\right.$ and $\left.\delta^{15} \mathrm{~N}\right)$ signatures bi-plot for basal resources (green dots), invertebrates (red diamonds), and fishes (black triangles) in the midstream of the Chishui River.

There was also a significant difference in $\delta^{13} \mathrm{C}$ and $\delta^{15} \mathrm{~N}$ values among different sorts of consumers (Kruskal-Wallis ANOVA, $p<0.01$ ). Compared with the basal resources in the midstream of the Chishui River, the $\delta^{13} \mathrm{C}$ and $\delta^{15} \mathrm{~N}$ values of consumers were more enriched. The $\delta^{13} \mathrm{C}$ values of consumers ranged from $-25.66 \pm 0.35 \%$ to $-21.21 \pm 0.07 \%$, with the most depleted $\delta^{13} \mathrm{C}$ values in the zooplankton and the most enriched $\delta^{13} \mathrm{C}$ values in the fish species Megalobrama pellegrini (Table 1, Figure 2). The $\delta^{15} \mathrm{~N}$ values of consumers changed from $3.00 \pm 0.30 \%$ for the most depleted $\delta^{15} \mathrm{~N}$ values in the mollusk species Bellamya quadrata to $12.81 \pm 0.00 \%$ for the most enriched $\delta^{15} \mathrm{~N}$ values in the fish species Siniperca scherzeri (Table 1, Figure 2).

Food chain length in the midstream of the Chishui River consisted of four trophic levels and the trophic levels of consumers ranged from 1.58 to 4.47 , of which the lowest trophic level was composed of the mollusk species Bellamya quadrata and the highest trophic level was occupied by the fish species Siniperca scherzeri (Table 1). Consumers at lower trophic levels were mainly invertebrates (mollusks and aquatic insects) that showed more depleted $\delta^{15} \mathrm{~N}$ values and their trophic levels ranged from 1.58 to 2.80, whereas the higher trophic levels were dominated by fish whose trophic levels ranged from 2.40 to 4.47 (Figure 2).

\subsection{Trophic Guilds and Trophic Niche}

Based on the stable isotope signatures and feeding types, the fish in the midstream of the Chishui River could be classified into four trophic guilds ( $92 \%$ similarity level): herbivores (Guild I), herbivore-based omnivores (Guild II), carnivore-based omnivores (Guild III), and carnivores (Guild IV) (Figure 3). Herbivores (Guild I) and herbivore-based omnivores (Guild II) represent the lower trophic levels, while the higher trophic levels are occupied by the trophic guilds of carnivore-based omnivores (Guild III) and carnivores (Guild IV). The result of the NMDS ordination was in good agreement with the guild classification by hierarchical cluster analysis (Figure 3). The $\delta^{13} \mathrm{C}$ and $\delta^{15} \mathrm{~N}$ values among trophic guilds were significantly different by the ANOSIM test $(p<0.05)$ (Table 2$)$. The NMDS ordination and ANOSIM tests verified the results of the trophic guild classification of fish in the midstream of the Chishui River. 

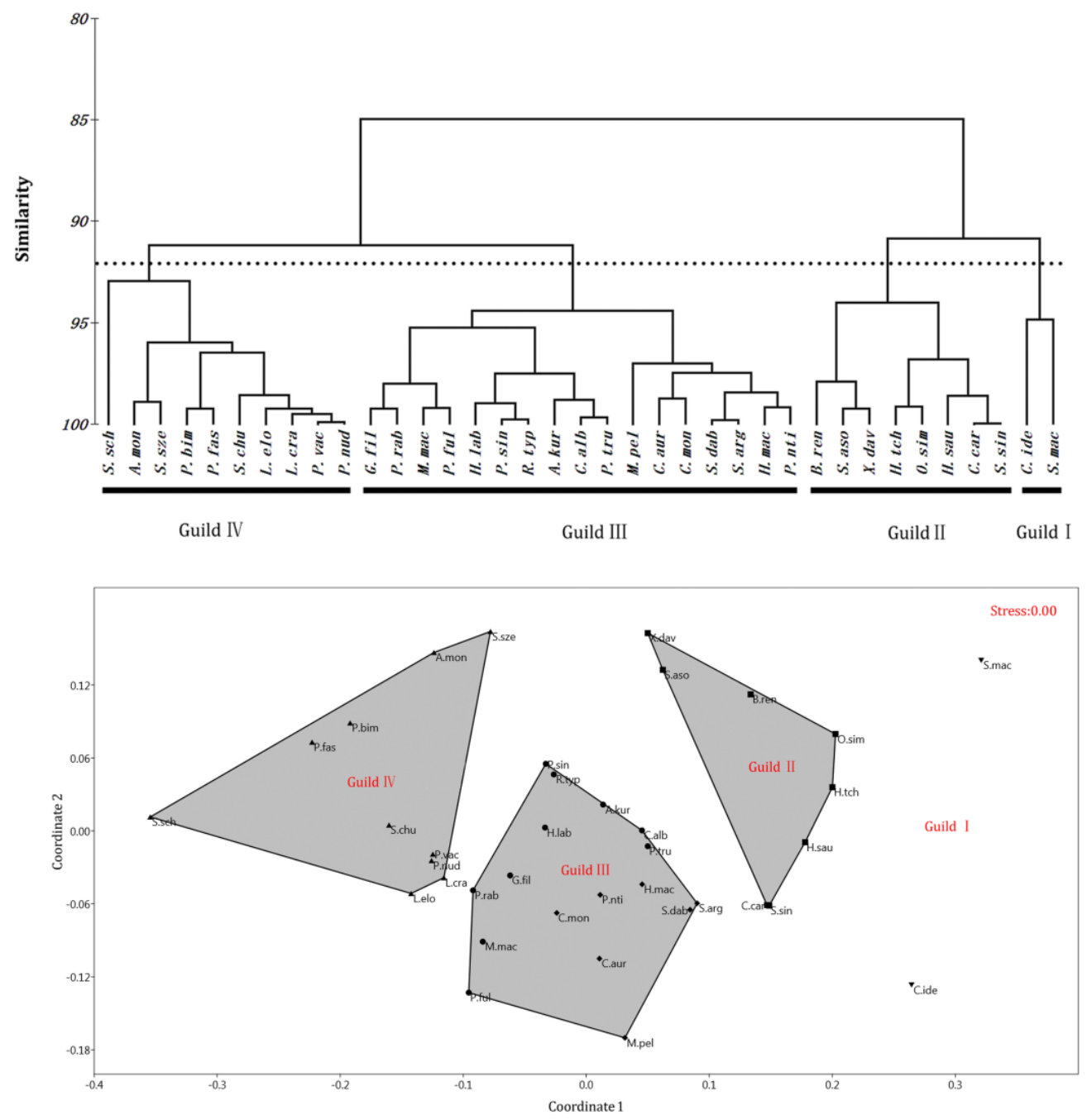

Figure 3. Hierarchical cluster analysis (Bray-Curtis similarity) and non-metric multidimensional scaling (NMDS) ordination based on $\delta^{13} \mathrm{C}$ and $\delta^{15} \mathrm{~N}$ signatures for trophic guilds of fish in the midstream of the Chishui River. Guild I represents herbivores; Guild II represents herbivore-based omnivores; Guild III represents carnivore-based omnivores; Guild IV represents carnivores.

Table 2. Analysis of similarity (ANOSIM) to each pair of trophic guilds of fish in the midstream of the Chishui River.

\begin{tabular}{ccccc}
\hline ANOSIM & Guild I & Guild II & Guild III & Guild IV \\
\hline Guild I & & 0.02 & 0.01 & 0.01 \\
Guild II & 0.56 & & 0.00 & 0.00 \\
Guild III & 0.99 & 0.72 & & 0.00 \\
Guild IV & 1.00 & 0.94 & 0.60 & \\
\hline
\end{tabular}

Guild I represents herbivores; Guild II represents herbivore-based omnivores; Guild III represents carnivore-based omnivores; Guild IV represents carnivores.

As the metrics of trophic niche have shown, the guild of herbivores (Guild I) had higher values in the $\delta^{13} \mathrm{C}$ range (CR) and the guild of carnivores (Guild IV) had higher values in the $\delta^{15} \mathrm{~N}$ range (NR); the corrected standard ellipse area (SEAc), the total area of the convex hull (TA), and the mean distance to the centroid (CD) were also larger for carnivores (Guild IV) and herbivores (Guild I) (Table 3, Figure 4). These results indicate that herbivores (Guild I) and carnivores (Guild IV) exhibited greater trophic diversity. However, the herbivore-based omnivores (Guild II) and carnivore-based omnivores (Guild III) exhibited 
lower mean nearest neighbor distance (MNND) and standard deviation of nearest neighbor distance (SDNND), which indicates that the omnivores had higher trophic redundancy (Table 3, Figure 4).

Table 3. Trophic niche metrics for trophic guilds of fish in the midstream of the Chishi River.

\begin{tabular}{ccccc}
\hline Metrics & Guild I & Guild II & Guild III & Guild IV \\
\hline NR & 0.02 & 1.91 & 1.99 & 2.71 \\
CR & 3.02 & 2.22 & 2.29 & 2.49 \\
SEAc & - & 1.85 & 1.45 & 2.62 \\
TA & - & 1.76 & 3.26 & 3.49 \\
CD & 1.51 & 1.03 & 0.84 & 1.04 \\
MNND & - & 0.39 & 0.34 & 0.46 \\
SDNND & - & 0.27 & 0.19 & 0.44 \\
\hline
\end{tabular}

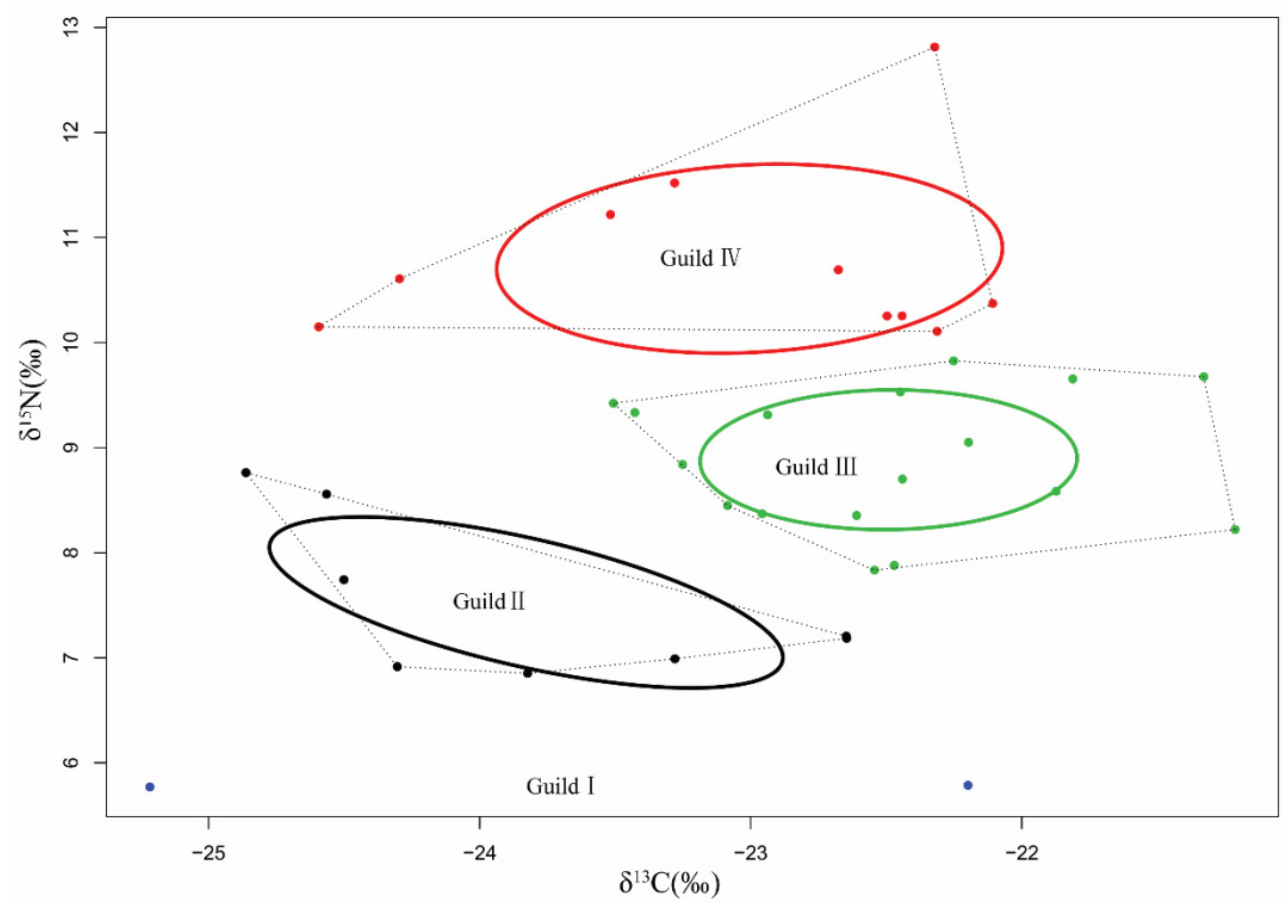

Figure 4. Isotopic niche for trophic guilds of fish in the midstream of the Chishui River.

\subsection{Contributions of Basal Resources to Consumers}

Periphyton presented the greatest contribution to zooplankton (average $24 \%$ ), mollusks (average 65\%), crustaceans (average $48 \%$ ) and aquatic insects (average $36 \%$ ), and the POM and SOM contributed subordinately to zooplankton and aquatic insects (average $18-19 \%$ ) (Table 4). For the trophic guilds of fish, the periphyton (average 33\%) contributed greatly to herbivores (Guild I), while POM (average 20\%) had a minor contribution to this guild. Phytoplankton (average 44\%) and periphyton (average 45\%) contributed significantly to herbivore-based omnivores (Guild II), and phytoplankton contributed mostly to carnivore-based omnivores (Guild III) and carnivores (Guild IV), with an average contribution rate of $77 \%$ and $95 \%$, respectively (Table 4). These results indicate that phytoplankton and periphyton were fundamental nutrient sources in the midstream of the Chishui River. 
Table 4. Contributions (95\% Bayesian credible interval) of basal resources to consumers in the midstream of the Chishui River.

\begin{tabular}{|c|c|c|c|c|c|c|c|c|c|c|c|c|}
\hline \multirow{2}{*}{ Consumers } & \multicolumn{2}{|c|}{$\begin{array}{l}\text { Aquatic Vascular } \\
\text { Plants }\end{array}$} & \multicolumn{2}{|c|}{$\begin{array}{l}\text { Terrestrial Vascular } \\
\text { Plants }\end{array}$} & \multicolumn{2}{|c|}{ Phytoplankton } & \multicolumn{2}{|c|}{ Periphyton } & \multicolumn{2}{|c|}{ POM } & \multicolumn{2}{|c|}{ SOM } \\
\hline & Range & Mean & Range & Mean & Range & Mean & Range & Mean & Range & Mean & Range & Mean \\
\hline \multicolumn{13}{|l|}{ Invertebrates } \\
\hline Zooplankton & $0.00-0.25$ & 0.11 & $0.00-0.29$ & 0.14 & $0.00-0.29$ & 0.14 & $0.06-0.40$ & 0.24 & $0.00-0.36$ & 0.19 & $0.00-0.35$ & 0.18 \\
\hline Mollusks & $0.00-0.10$ & 0.04 & $0.00-0.14$ & 0.05 & $0.00-0.14$ & 0.05 & $0.42-0.86$ & 0.65 & $0.00-0.30$ & 0.12 & $0.00-0.26$ & 0.10 \\
\hline Crustaceans & $0.00-0.17$ & 0.06 & $0.00-0.22$ & 0.07 & $0.00-0.29$ & 0.13 & $0.16-0.75$ & 0.48 & $0.00-0.35$ & 0.15 & $0.00-0.29$ & 0.11 \\
\hline $\begin{array}{c}\text { Aquatic inserts } \\
\text { Fish }\end{array}$ & $0.00-0.22$ & 0.08 & $0.00-0.28$ & 0.11 & $0.00-0.25$ & 0.09 & $0.10-0.67$ & 0.36 & $0.00-0.38$ & 0.18 & $0.00-0.37$ & 0.18 \\
\hline Guild I & $0.00-0.23$ & 0.09 & $0.00-0.25$ & 0.10 & $0.00-0.22$ & 0.11 & $0.11-0.60$ & 0.33 & $0.00-0.39$ & 0.20 & $0.00-0.35$ & 0.17 \\
\hline Guild II & $0.00-0.05$ & 0.02 & $0.00-0.06$ & 0.02 & $0.32-0.54$ & 0.44 & $0.33-0.56$ & 0.45 & $0.00-0.14$ & 0.05 & $0.00-0.08$ & 0.03 \\
\hline Guild III & $0.00-0.02$ & 0.01 & $0.00-0.02$ & 0.01 & $0.72-0.83$ & 0.77 & $0.13-0.25$ & 0.19 & $0.00-0.02$ & 0.02 & $0.00-0.03$ & 0.01 \\
\hline Guild IV & $0.00-0.02$ & 0.01 & $0.00-0.02$ & 0.01 & $0.90-0.99$ & 0.95 & $0.00-0.04$ & 0.02 & $0.00-0.03$ & 0.01 & $0.00-0.02$ & 0.01 \\
\hline
\end{tabular}




\section{Discussion}

\subsection{Trophic Position}

The $\delta^{13} \mathrm{C}$ values of basal resources varied from $-32.14 \%$ to $-21.54 \%$ and consumers ranged from $-25.66 \%$ to $-21.21 \%$ (Table 1, Figure 2). Significant differences in $\delta^{13} \mathrm{C}$ values among the sorts of basal resource indicated various transformations of basic energy through the food web $[53,54]$. We found that $\delta^{13} \mathrm{C}$ values were increased moving up the trophic level, but the increases were not so evident, and the $\delta^{13} \mathrm{C}$ values of consumers were closer to the $\delta^{13} \mathrm{C}$ values of periphyton and phytoplankton, suggesting that periphyton and phytoplankton may be the primary energy source for the food web. The divergence of $\delta^{13} \mathrm{C}$ values among the sorts of basal resources in our study are consistent with previous research, which enabled us to effectively discriminate different sources of carbon transfers to the food web in riverine ecosystems $[29,55,56]$. Moreover, the $\delta^{15} \mathrm{~N}$ values of basal resources were simultaneously depleted from $0.97 \%$ to $6.36 \%$ and consumers ranged from $3.00 \%$ o to $12.81 \%$ (Table 1, Figure 2). The $\delta^{15} \mathrm{~N}$ values were gradually increased moving up the food chain, indicating that different sorts of basal resources and consumers were situated in distinct trophic positions in the food web $[57,58]$. We also found that the phytoplankton had higher $\delta^{15} \mathrm{~N}$ values than some consumers, indicating the rapid response of phytoplankton to physiology and habitat changes. The characteristics of various transformations in $\delta^{13} \mathrm{C}$ values and continuous increases in $\delta^{15} \mathrm{~N}$ values with the food chain for basal resources and consumers suggest that there were multiple trophic pathways in the midstream of the Chishui River.

We selected the mollusk species Limnoperna lacustris as the baseline organism to calculate the trophic level of consumers. This is in concordance with Post [31] and Vander Zanden [59], who summarized that zooplankton, mussels, and snails are suited to being employed as baseline organisms in numerous aquatic ecosystems because of their slow isotope turnover and stable response to environmental variation. The food chain length in the midstream of the Chishui River consisted of four trophic levels, in which invertebrates and herbivorous fish (Guild I) were at a lower trophic level, omnivorous fish (Guild II and Guild III) mainly belonged to the second or third trophic level, and carnivorous fish (Guild IV) occupied the highest trophic level (Figures 2 and 4). The characteristics of food chain length in our study are similar to studies in the Deluge Inlet, Australia [60] and North Selangor Peat Swamp, Malaysia [4], which demonstrated that riverine ecosystems with high productivity could support such long food chain lengths.

Our findings indicate that the riverine ecosystem in the midstream of the Chishui River sustained multiple trophic pathways and long food chain length (top trophic level at 4.47 for the fish species of Siniperca scherzeri), which indicates a high ecosystem productivity in this area [61]. The results correspond to the energetic hypothesis which states that the food chain length is generally maintained at three to four trophic levels and not higher than six trophic levels, as the food chain length is often restricted by the availability of limiting food resources, and energetic transfer efficiencies along the food chain are typically low $[14,62,63]$. Current research has shown that dam constructions breaking the connectivity of riverine ecosystems would consequently affect the energy transfer and shift species composition (especially for endemic fish species) of food webs in riverine ecosystem due to the changes in hydrological conditions and barrier effects $[64,65]$. For instance, Wang et al. [64] determined the food chain length in the Three Gorges reservoir area and found that the food chain length in this area mainly consisted of three trophic levels. Kaymak et al. [13] also found that impoundment provided a highly homogeneous habitat for basal resources, such as phytoplankton, and led to primary consumers having a more simplified diet, which caused a decrease in trophic pathways and food chain length in riverine ecosystems. This supports the notion that the strategy to keep the Chishui River undammed is crucial for the conservation of endemic aquatic organisms and the preservation of a highly productive and diverse food web. 


\subsection{Trophic Niche}

The metrics of isotopic niche can be used to quantitatively analyze stable isotope representations of trophic niches, and provide empirical and conceptual examples for trophic diversity and redundancy related to ecosystem stability [15]. In this study, herbivorous fish (Guild I) and carnivorous fish (Guild IV) possessed a greater trophic diversity, while omnivorous fish (Guild II and Guild III) held a higher trophic redundancy in the midstream of the Chishui River (Table 3, Figure 4). Our findings show that the high degree of trophic diversity and redundancy, with evenly distributed trophic interactions among coexisting species of fish, promotes a stable trophic niche structure in the midstream of the Chishui River. Similar results have been observed in several other aquatic ecosystems (e.g., [28,66]), which showed that high trophic diversity and redundancy were necessary to maintain ecosystem stability for increasing the channel of resource utilizations and the ability to resist external disturbances.

Nevertheless, Hadwen and Arthington [67] and Hoeinghaus et al. [14] showed that pollutant inputs and dam construction in riverine ecosystems can have significant effects on ecosystem stability. For example, East [55] found that sampling sites with high nutrient inputs had lower $\delta^{13} \mathrm{C}$ ranges, $\delta^{15} \mathrm{~N}$ ranges, and total area of the convex hull (TA) in the Pecos River, United States. Kaymak et al. [13] reported that trophic diversity and redundancy were decreased for the fish assemblage upstream of the dam in the Tozanli River, Turkey. Furthermore, the findings by Wang et al. [64] suggested that the negative impacts on the trophic diversity and redundancy from reduced flow and increased water depth occurred after the completion of the Three Gorges Dam. These results demonstrate that anthropogenic impacts can directly influence the trophic niche structure in riverine ecosystems. Here, we consider the midstream of the Chishui River to have a high degree of ecosystem stability and to be less affected by anthropogenic impacts, so it is a last refuge for endemic fish and other aquatic organisms in the upper Yangtze River.

\subsection{Carbon Source}

In this study, the autochthonous organic matter from phytoplankton and periphyton plays an essential role in providing basic energy for the food web in the midstream of the Chishui River (Table 4). Likewise, Delong et al. [68] analyzed the linkages between food sources and consumers in the upper and middle Mississippi River, United States, and illustrated that autochthonous carbon was the basic carbon source for the food web in the main channel. Autochthonous organic matter was also considered to be a key carbon source in tropical and subtropical riverine ecosystems, such as middle Cooper Creek, Australia [69] and Teles Pires River, Brazil [70]. In contrast, Wang et al. [71] and Winemiller et al. [72] proposed that allochthonous organic matter from the terrestrial parts contributed significantly to the food web of the middle Yangtze River, China, and Monkey River, Belize, respectively.

The results of our study suggest that autochthonous productivity is the dominant carbon source for the food web in the midstream of the Chishui River. This indicates that the riverine productivity concept is more applicable in the midstream of the Chishui River [22]. Additionally, the basal resources of POM and SOM also provided a certain amount of contributions to the food web, implying that allochthonous carbon sources from terrestrial parts may provide supplementary energy supports [20,21]. Zhang et al. [36] and Liu [37] also examined the food source of the headwater and lower reaches of the Chishui River and demonstrated that algae supplied the most energy to the food web. Hence, we infer that autochthonous organic matter probably provides the key energy support for food webs in riverine ecosystems of tropical and subtropical mountains [73,74].

Specifically, Thorp et al. [23] recognized that most suspended organic carbon from terrestrial parts is refractory within the riverine ecosystem and is difficult for consumers to assimilate. Therefore, the quantity and quality of labile autochthonous organic matter would make it a more suitable and digestible carbon source than the more refractory allochthonous organic matter transported from upstream or the floodplain [23,75]. Several 
studies have shown that human modification by constructing dams changed the natural conditions, which alters the carbon source for a large proportion of riverine ecosystems in the world [19,64]. Yao [76] explored the carbon sources and showed that terrestrial carbon sources have an important contribution to the fish communities in the Three Gorges Reservoir, and the contribution will continue to increase with the ascension of water storage. However, it is still not clear whether the major energy resources may be altered in dammed rivers, for example from autochthonous to allochthonous. Yet the Chishui River, as the only undammed tributary supported by autochthonous productivity in the upper Yangtze River basin, still remains in a natural and healthy condition.

\section{Conclusions}

In summary, dam construction in the upper Yangtze River has caused severe habitat fragmentation for endemic aquatic organisms, especially for fish. The Chishui River, as the only tributary without damming in the upper Yangtze River basin, deserves great attention. Our study on energy flows and nutrient pathways provides the evidence that there are multiple trophic pathways, a long food chain length, a stable trophic niche structure and autochthonous productivity for the food web in the midstream of the Chishui River. This evidence indicates that the midstream of the Chishui River is an essential habitat for the conservation of endemic fish and other organisms in the upper Yangtze River, and is therefore of great conservation value. We propose that the Chishui River should remain undammed in the future to facilitate the conservation of the biodiversity it supports.

Author Contributions: Conceptualization, Q.Q. and H.L.; methodology, Q.Q. and H.L.; investigation, F.L. and F.Z.; data curation, Q.Q. and C.W.; writing-original draft preparation, Q.Q.; writingreview and editing, Q.Q. and H.L. All authors have read and agreed to the published version of the manuscript.

Funding: This research was funded by the Strategic Priority Research Program of the Chinese Academy of Sciences (XDA23000000), the Biodiversity Survey and Assessment Project of the Ministry of Ecology and Environment, China (2019HJ2096001006), the National Natural Science Foundation of China (31400359), and the China Three Gorges Corporation (0799574).

Institutional Review Board Statement: The study was conducted according to the guidelines of the Declaration of Helsinki, and approved by the Ethics Committee of Institute of Hydrobiology, Chinese Academy of Sciences (IACUC protocol No. 152342-5714).

Informed Consent Statement: Not applicable.

Data Availability Statement: Data was contained within the article.

Acknowledgments: We thank Zhi Zhang, Lin Chen, Xue Wang and other colleagues for the assistance in field sampling. We thank Xin Gao for providing valuable advice on the manuscript. We also thank three anonymous reviewers for their valuable comments on the manuscript.

Conflicts of Interest: The authors declare no conflict of interest.

\section{References}

1. Vadeboncoeur, Y.; Lodge, D.M.; Carpenter, S.R. Whole-lake fertilization effects on distribution of primary production between benthic and pelagic habitats. Ecology 2001, 82, 1065-1077. [CrossRef]

2. Andrade, C.; Ríos, C.; Gerdes, D.; Brey, T. Trophic structure of shallow-water benthic communities in the sub-Antarctic Strait of Magellan. Polar Biol. 2016, 39, 2281-2297. [CrossRef]

3. Mieczan, T.; Michał, N.; Adamczuk, M.; Bielańska-Grajner, I. Stable isotope analyses revealed high seasonal dynamics in the food web structure of a peatbog. Int. Rev. Hydrobiol. 2015, 100, 141-150. [CrossRef]

4. Joni, A.A.M.; Zulkifli, S.Z.; Mohamat-Yusuff, F.; Hanapiah, M.; Mukhtar, A.; Ismail, A.; Miyazaki, N. Utilization of Dual Stable Isotope Markers $\left(\delta^{13} \mathrm{C}\right.$ and $\left.\delta^{15} \mathrm{~N}\right)$ to Determine Trophic Structure in Aquatic Environment of Malaysian Peat Swamp Forest. Procedia Environ. Sci. 2015, 30, 250-255. [CrossRef]

5. Hoeinghaus, D.J.; Vieira, J.P.; Costa, C.S.; Bemvenuti, C.E.; Winemiller, K.O.; Garcia, A.M. Estuary hydrogeomorphology affects carbon sources supporting aquatic consumers within and among ecological guilds. Hydrobiologia 2011, 673, 79-92. [CrossRef]

6. Norkko, A.; Thrush, S.F.; Cummings, V.J.; Gibbs, M.M.; Andrew, N.L.; Norkko, J.; Schwarz, A.-M. Trophic structure of coastal Antarctic food webs associated with changes in sea ice and food supply. Ecology 2007, 88, 2810-2820. [CrossRef] 
7. Hussey, N.E.; Macneil, M.A.; McMeans, B.C.; Olin, J.A.; Dudley, S.F.J.; Cliff, G.; Wintner, S.P.; Fennessy, S.T.; Fisk, A.T. Rescaling the trophic structure of marine food webs. Ecol. Lett. 2014, 17, 239-250. [CrossRef]

8. López-Rodríguez, A.; Silva, I.; Ávila-Simas, S.; Stebniki, S.; Bastian, R.; Massaro, V.; Pais, J.; Tesitore, G.; Teixeira de Mello, F.; D'Anatro, A.; et al. Diets and Trophic Structure of Fish Assemblages in a Large and Unexplored Subtropical River: The Uruguay River. Water 2019, 11, 1374. [CrossRef]

9. Delong, M.D. Food webs and the Upper Mississippi River: Contributions to our understanding of ecosystem function in large rivers. Hydrobiologia 2010, 640, 89-101. [CrossRef]

10. Wollrab, S.; Diehl, S.; De Roos, A.M. Simple rules describe bottom-up and top-down control in food webs with alternative energy pathways. Ecol. Lett. 2012, 15, 935-946. [CrossRef]

11. Schoener, T.W. Food Webs From the Small to the Large: The Robert H. MacArthur Award Lecture. Ecology 1989, 70, 1559-1589. [CrossRef]

12. Hutchinson, G.E. Homage to Santa Rosalia or Why Are There So Many Kinds of Animals? Am. Nat. 1959, 93, 145-159. [CrossRef]

13. Kaymak, N.; Winemiller, K.O.; Akin, S.; Altuner, Z.; Polat, F.; Dal, T. Spatial and temporal variation in food web structure of an impounded river in Anatolia. Mar. Freshw. Res. 2018, 69, 1453-1471. [CrossRef]

14. Hoeinghaus, D.J.; Winemiller, K.O.; Agostinho, A.A. Hydrogeomorphology and river impoundment affect food-chain length of diverse Neotropical food webs. Oikos 2008, 117, 984-995. [CrossRef]

15. Layman, C.A.; Arrington, D.A.; Montaña, C.G.; Post, D.M. Can stable isotope ratios provide for community-wide measures of trophic structure? Ecology 2007, 88, 42-48. [CrossRef]

16. McCann, K. The Structure and Stability of Food Webs; Princeton University Press: Princeton, NJ, USA, 2009 ; pp. 305-311.

17. Odum, E.P. Basic Ecology; Saunders College Publishing: Philadelphia, PA, USA, 1983; pp. 46-50.

18. Pruell, R.J.; Taplin, B.K.; Lake, J.L.; Jayaraman, S. Nitrogen isotope ratios in estuarine biota collected along a nutrient gradient in Narragansett Bay, Rhode Island, USA. Mar. Pollut. Bull. 2006, 52, 612-620. [CrossRef]

19. Pingram, M.; Collier, K.; Hamilton, D.; David, B.; Hicks, B. Carbon Sources Supporting Large River Food Webs: A Review of Ecological Theories and Evidence from Stable Isotopes. Freshw. Rev. 2012, 5, 85-103. [CrossRef]

20. Vannote, R.L.; Minshall, G.W.; Cummins, K.W.; Sedell, J.R.; Cushing, C.E. The River Continuum Concept. Can. J. Fish. Aquat. Sci. 1980, 37, 130-137. [CrossRef]

21. Junk, W.J.; Bayley, P.B.; Sparks, R.E. The flood pulse concept in river-floodplain systems. Can. Spec. Publ. Fish. Aquat. Sci. 1989, $106,110-127$.

22. Thorp, J.H.; Delong, M.D. The Riverine Productivity Model: An Heuristic View of Carbon Sources and Organic Processing in Large River Ecosystems. Oikos 1994, 70, 305-308. [CrossRef]

23. Thorp, J.H.; Delong, M.D.; Greenwood, K.S.; Casper, A.F. Isotopic analysis of three food web theories in constricted and floodplain regions of a large river. Oecologia 1998, 117, 551-563. [CrossRef] [PubMed]

24. Huang, I.-Y.; Lin, Y.-S.; Chen, C.-P.; Hsieh, H.-L. Food web structure of a subtropical headwater stream. Mar. Freshw. Res. 2007, 58, 596-607. [CrossRef]

25. Angradi, T.R. Trophic Linkages in the Lower Colorado River: Multiple Stable Isotope Evidence. J. N. Am. Benthol. Soc. 1994, 13, 479-495. [CrossRef]

26. Opsahl, S.P.; Golladay, S.W.; Smith, L.L.; Allums, S.E. Resource-Consumer Relationships and Baseline Stable Isotopic Signatures of Food Webs in Isolated Wetlands. Wetlands 2010, 30, 1213-1224. [CrossRef]

27. Fisher, S.J.; Brown, M.L.; Willis, D.W. Temporal food web variability in an upper Missouri River backwater: Energy origination points and transfer mechanisms. Ecol. Freshw. Fish 2001, 10, 154-167. [CrossRef]

28. Iglesias, C.; Meerhoff, M.; Johansson, L.S.; González-Bergonzoni, I.; Mazzeo, N.; Pacheco, J.P.; Mello, F.T.-d.; Goyenola, G.; Lauridsen, T.L.; Søndergaard, M.; et al. Stable isotope analysis confirms substantial differences between subtropical and temperate shallow lake food webs. Hydrobiologia 2017, 784, 111-123. [CrossRef]

29. Sepúlveda-Lozada, A.; Mendoza-Carranza, M.; Wolff, M.; Saint-Paul, U.; Ponce-Mendoza, A. Differences in food web structure of mangroves and freshwater marshes: Evidence from stable isotope studies in the Southern Gulf of Mexico. Wetl. Ecol. Manag. 2015, 23, 293-314. [CrossRef]

30. Bouwman, A.; Bierkens, M.F.P.; Griffioen, J.; Hefting, M.; Middelburg, J.; Middelkoop, H.; Slomp, C.P. Nutrient Dynamics, Transfer and Retention along the Aquatic Continuum from Land to Ocean: Towards Integration of Ecological and Biogeochemical Models. Biogeosci. Discuss. 2012, 9, 8733-8782. [CrossRef]

31. Post, D.M. Using stable isotopes to estimate trophic position: Models, methods, and assumptions. Ecology 2002, 83, 703-718. [CrossRef]

32. Manetta, G.; Benedito-Cecilio, E.; Martinelli, M. Carbon sources and trophic position of the main species of fishes of Baía River, Paraná River floodplain, Brazil. Braz. J. Biol. 2003, 63, 283-290. [CrossRef]

33. Layman, C.A.; Araujo, M.S.; Boucek, R.; Hammerschlag-Peyer, C.M.; Harrison, E.; Jud, Z.R.; Matich, P.; Rosenblatt, A.E.; Vaudo, J.J.; Yeager, L.A.; et al. Applying stable isotopes to examine food-web structure: An overview of analytical tools. Biol. Rev. 2012, 87, 545-562. [CrossRef] [PubMed]

34. Jiang, X.-M.; Xiong, J.; Qiu, J.-W.; Wu, J.-M.; Wang, J.-W.; Xie, Z.-C. Structure of Macroinvertebrate Communities in Relation to Environmental Variables in a Subtropical Asian River System. Int. Rev. Hydrobiol. 2010, 95, 42-57. [CrossRef] 
35. Wu, J. Status and Conservation of Fish Resources in the Chishui River. Ph.D. Thesis, University of Chinese Academy of Sciences, Beijing, China, 2011.

36. Zhang, F.; Liu, F.; Qin, Q.; Liu, H.; Cao, W.; Gao, X. Diet composition and trophic guild structure of fish assemblage in headwaters of the Chishui River, a tributary of the upper Yangtze River, China. Environ. Biol. Fishes 2018, 101, 1235-1248. [CrossRef]

37. Liu, F. Fish Community Ecology in the Chishui River. Ph.D. Thesis, University of Chinese Academy of Sciences, Beijing, China, 2013.

38. Wang, J. Fish Community Spatial Structure and Its Ecological Processes in the Chishui River Basin. Ph.D. Thesis, University of Chinese Academy of Sciences, Beijing, China, 2015.

39. Duan, X.; Wang, Z.; Xu, M. Benthic Macroinvertabrate and Application in the Assement of Stream Ecology; Tsinghua University Press: Beijing, China, 2010.

40. Morse, J.C.; Yang, L.; Tian, L. Aquatic Insects of China Useful for Monitoring Water Quality; Hohai University Press: Nanjing, China, 1994.

41. Ding, R. The Fishes of Sichuan, China; Sichuan Publishing House of Science and Technology: Chengdu, China, 1994.

42. Chen, Y.Y. Fauna Sinica-Osteichthyes Cyperiniformes II; Science Press: Beijing, China, 1998.

43. Fry, B. Using stable isotopes to monitor watershed influences on aquatic trophodynamics. Can. J. Fish. Aquat. Sci. 1999, 56, 2167-2171. [CrossRef]

44. Mendoza-Carranza, M.; Hoeinghaus, D.J.; Garcia, A.M.; Romero-Rodriguez, Á. Aquatic food webs in mangrove and seagrass habitats of Centla Wetland, a Biosphere Reserve in Southeastern Mexico. Neotrop. Ichthyol. 2010, 8, 171-178. [CrossRef]

45. Loc'h, F.L.; Hily, C. Stable carbon and nitrogen isotope analysis of Nephrops norvegicus/Merluccius merluccius fishing grounds in the Bay of Biscay (Northeast Atlantic). Can. J. Fish. Aquat. Sci. 2005, 62, 123-132. [CrossRef]

46. Mao, Z.; Gu, X.; Zeng, Q.; Zhou, L.; Sun, M. Food web structure of a shallow eutrophic lake (Lake Taihu, China) assessed by stable isotope analysis. Hydrobiologia 2012, 683, 173-183. [CrossRef]

47. Clarke, K.R.; Warwick, R.M. Change in Marine Communities: An Approach to Statistical Analysis and Interpretation. Mt. Sinai J. Med. N. Y. 1994, 40, 42-48. [CrossRef]

48. Parnell, A.C.; Inger, R.; Bearhop, S.; Jackson, A.L. Source Partitioning Using Stable Isotopes: Coping with Too Much Variation. PLoS ONE 2010, 5, e9672. [CrossRef]

49. deVries, M.S.; del Rio, C.M.; Tunstall, T.S.; Dawson, T.E. Isotopic Incorporation Rates and Discrimination Factors in Mantis Shrimp Crustaceans. PLoS ONE 2015, 10, e0122334. [CrossRef]

50. Hammer, Ø. PAST Paleontological Statistics Version 3.0: Reference Manual; University of Oslo: Oslo, Norway, 2013.

51. Clarke, K.R.; Gorley, R.; Somerfield, P.J.; Warwick, R. Change in Marine Communities: An Approach to Statistical Analysis and Interpretation; Primer-E Ltd: Auckland, New Zealand, 2014.

52. Jackson, A.L.; Inger, R.; Parnell, A.C.; Bearhop, S. Comparing isotopic niche widths among and within communities: SIBERStable Isotope Bayesian Ellipses in R. J. Anim. Ecol. 2011, 80, 595-602. [CrossRef] [PubMed]

53. Wardiatno, Y.; Mardiansyah, T.P.; Tsuchiya, M. Possible food sources of macrozoobenthos in the manko mangrove ecosystem, okinawa (Japan): A stable isotope analysis approach. Trop. Life Sci. Res. 2015, 26, 53-65. [PubMed]

54. Marchese, M.R.; Saigo, M.; Zilli, F.L.; Capello, S.; Devercelli, M.; Montalto, L.; Paporello, G.; Wantzen, K.M. Food webs of the Paraná River floodplain: Assessing basal sources using stable carbon and nitrogen isotopes. Limnologica 2014, 46, 22-30. [CrossRef]

55. East, J.L. Spatial and Temporal Variation in Aquatic Food-Web Structure in the Pecos River in New Mexico and Texas, USA. Master's Thesis, Texas Tech University, Lubbock, TX, USA, 2015.

56. Jespen, D.B.; Winemiller, K.O. Strucuture of tropical river food webs by stable isotope ratios. Oikos 2002, 96, 46-55.

57. Mazumder, D.; Saintilan, N.; Williams, R.J.; Szymczak, R. Trophic importance of a temperate intertidal wetland to resident and itinerant taxa: Evidence from multiple stable isotope analyses. Mar. Freshw. Res. 2011, 62, 11. [CrossRef]

58. Kang, C.-K.; Choy, E.J.; Son, Y.; Lee, J.-Y.; Kim, J.K.; Kim, Y.; Lee, K.-S. Food web structure of a restored macroalgal bed in the eastern Korean peninsula determined by $\mathrm{C}$ and N stable isotope analyses. Mar. Biol. 2008, 153, 1181-1198. [CrossRef]

59. Vander Zanden, M.J.; Casselman, J.M.; Rasmussen, J.B. Stable isotope evidence for the food web consequences of species invasions in lakes. Nature 1999, 401, 464-467. [CrossRef]

60. Abrantes, K.; Sheaves, M. Food web structure in a near-pristine mangrove area of the Australian Wet Tropics. Estuar. Coast. Shelf Sci. 2009, 82, 597-607. [CrossRef]

61. Post, D.M. The long and short of food-chain length. Trends Ecol. Evol. 2002, 17, 269-277. [CrossRef]

62. Carlier, A.; Riera, P.; Amouroux, J.M.; Bodiou, J.Y.; Desmalades, M.; Gremare, A. Food web structure of two Mediterranean lagoons under varying degree of eutrophication. J. Sea Res. 2008, 60, 264-275. [CrossRef]

63. Du, J.; Zheng, X.; Peristiwady, T.; Liao, J.; Ch. Makatipu, P.; Yin, X.; Hu, W.; Koagouw, W.; Chen, B. Food sources and trophic structure of fishes and benthic macroinvertebrates in a tropical seagrass meadow revealed by stable isotope analysis. Mar. Biol. Res. 2016, 12, 748-757. [CrossRef]

64. Wang, J.; Li, L.; Xu, J.; Gu, B. Initial response of fish trophic niche to hydrological alteration in the upstream of Three Gorges Dam. Ecol. Process. 2016, 5, 11. [CrossRef]

65. Gao, X.; Fujiwara, M.; Winemiller, K.O.; Lin, P.; Li, M.; Liu, H. Regime shift in fish assemblage structure in the Yangtze River following construction of the Three Gorges Dam. Sci. Rep. 2019, 9, 4212. [CrossRef] [PubMed] 
66. Baiser, B.; Ardeshiri, R.S.; Ellison, A.M. Species Richness and Trophic Diversity Increase Decomposition in a Co-Evolved Food Web. PLoS ONE 2011, 6, e20672. [CrossRef] [PubMed]

67. Hadwen, W.L.; Arthington, A.H. Food webs of two intermittently open estuaries receiving ${ }^{15} \mathrm{~N}$-enriched sewage effluent. Estuar. Coast. Shelf Sci. 2007, 71, 347-358. [CrossRef]

68. Delong, M.D.; Thorp, J.H.; Greenwood, K.S.; Miller, M.C. Responses of consumers and food resources to a high magnitude, unpredicted flood in the upper Mississippi River basin. Regul. Rivers Res. Manag. 2001, 17, 217-234. [CrossRef]

69. Bunn, S.E.; Davies, P.M.; Winning, M. Sources of organic carbon supporting the food web of an arid zone floodplain river. Freshw. Biol. 2003, 48, 619-635. [CrossRef]

70. Dary., E.P.; Feereira, E.; Zuanon, J.; Ropek., C.P. Diet and trophic structure of the fish assemblage in the mid-course of the Teles Pires River, Tapajós River basin, Brazil. Neotrop. Ichthyol. 2017, 15, e160173. [CrossRef]

71. Wang, J.; Gu, B.; Huang, J.; Han, X.; Lin, G.; Zheng, F.; Li, Y. Terrestrial Contributions to the Aquatic Food Web in the Middle Yangtze River. PLoS ONE 2014, 9, e102473. [CrossRef]

72. Winemiller, K.O.; Hoeinghaus, D.J.; Pease, A.A.; Esselman, P.C.; Honeycutt, R.L.; Gbanaador, D.; Carrera, E.; Payne, J. Stable isotope analysis reveals food web structure and watershed impacts along the fluvial gradient of a Mesoamerican coastal river. River Res. Appl. 2011, 27, 791-803. [CrossRef]

73. Medeiros, E.S.F.; Arthington, A.H. Allochthonous and autochthonous carbon sources for fish in floodplain lagoons of an Australian dryland river. Environ. Biol. Fishes 2011, 90, 1-17. [CrossRef]

74. March, J.G.; Pringle, C.M. Food Web Structure and Basal Resource Utilization along a Tropical Island Stream Continuum, Puerto Rico. Biotropica 2003, 35, 84-93. [CrossRef]

75. Zeug, S.C.; Winemiller, K.O. Evidence supporting the importance of terrestrial carbon in a large-river food web. Ecology 2008, 89, 1733-1743. [CrossRef] [PubMed]

76. Yao, X. Trophic Niches of Fishes Along the Yangzi River Near the Three Gorges Dam. Master's Thesis, University of Chinese Academy of Sciences, Beijing, China, 2017. 